Volume 13, Issue 1 (Winter 2021)

\title{
Learned Fable, Living World: Artistry, Knowledge and Attention to Nature in Two Aesopic Paintings by Joannes Fyt
}

Thomas Balfe

thomas.balfe@courtauld.ac.uk

Recommended Citation:

Thomas Balfe, "Learned Fable, Living World: Artistry, Knowledge and Attention to Nature in Two Aesopic Paintings by Joannes Fyt," Journal of Historians of Netherlandish Art 13:1 (Winter 2021) DOI: 10.5092/jhna.2021.13.1.3

Available at https://jhna.org/articles/learned-fable-living-world-artistry-knowledge-and-attention-to-nature-in-two-aesopic-paintings-by-joannes-fyt/

Published by Historians of Netherlandish Art: https://hnanews.org/

Republication Guidelines: https://jhna.org/republication-guidelines/

Notes: This PDF is provided for reference purposes only and may not contain all the functionality or features of the original, online publication. This PDF provides paragraph numbers as well as page numbers for citation purposes.

ISSN: 1949-9833 


\title{
Learned Fable, Living World: Artistry, Knowledge and Attention to Nature in Two Aesopic Paintings by Joannes Fyt
}

\author{
Thomas Balfe
}

Now better known as a hunting painter, the Antwerp animal specialist Joannes Fyt (1611-1661) also produced several depictions of Aesopic fables. A notable feature of Fyt's fables is their attentiveness to the appearances and behaviors of animals and how they inhabit their environment. Focusing on two paintings by Fyt featuring poultry birds, this essay uses period fable books, a key discussion of fable by Erasmus, and zoopoetic theory to explore how these works address both the allegorical realm of fable and a tangible living world that was increasingly coming under investigation from natural history and related modes of inquiry.

Prior to the sixteenth century, Aesopic works in Latin and in vernacular languages enjoyed great popularity throughout the Low Countries. ${ }^{1}$ With the 1567 publication of Edewaerd de Dene's (1505-1578) fable book called De Warachtige fabulen der dieren (The Truthful Fables of the Animals), the genre took on an even more important role in the region's literary and visual culture. ${ }^{2}$ Containing 107 verse fables, each paired with an etching by the artist Marcus Gheeraerts (ca. 1520-ca. 1590), de Dene's collection provided the impetus for a new mode of fable painting that was initiated by Rubens and significantly developed by Frans Snyders (1579-1657). ${ }^{3}$ Inspired by Snyders's example, and sometimes under his direct tutelage, the genre was later taken up by younger painters, including Paul de Vos (ca. 1591-1578), Pieter Boel (1622-1674), and Jan van Kessel the Elder (1626-1679), who went on to turn it into one of the seventeenth century's most innovative forms of animal depiction. ${ }^{4}$

2 My essay focuses on another Flemish artist whose fable paintings have received somewhat less attention: the animal specialist Joannes Fyt (1611-1661), whose most productive working years (ca. 1638-61) were spent in the city of Antwerp, within the Catholic, Habsburg-governed south- 
ern Netherlands. Returning to Antwerp in the late 1630s after spending the first decade of his career abroad, Fyt worked briefly in Snyders's studio, where he would have had access to his older colleague's two Aesopic fable books, before going on to forge a successful career through the rapid production of hunting scenes and still lifes with dead game. ${ }^{5}$ His engagement with fable is a departure from his regular output and amounts to just four pictures, two of which exist in variant copies. ${ }^{6}$ Prior scholarship on these works by Arnout Balis, Susan Koslow, and Lisanne Wepler has mainly examined how they adapt their literary and visual sources, the social context in which they were received, and their narrative strategies. ${ }^{7}$ By contrast, my discussion will concentrate on a distinctive pictorial feature of Fyt's Aesopic works - the meticulous attention they pay to how animals move, gesticulate, sustain themselves, and inhabit their environment. By considering two paintings, The Cock and the Jewel ("Gallinero") (fig. 1) and The Flemish Cock and the Turkey Cock (fig. 2), I will argue that this aspect of Fyt's fable pictures would have been understood and appreciated in terms of the value placed on images that were thought to retain close contact with the "life" of the subjects they depict, in contexts spanning the modern divide between science and art, and between realism and modes of representation in which imagination is more central.

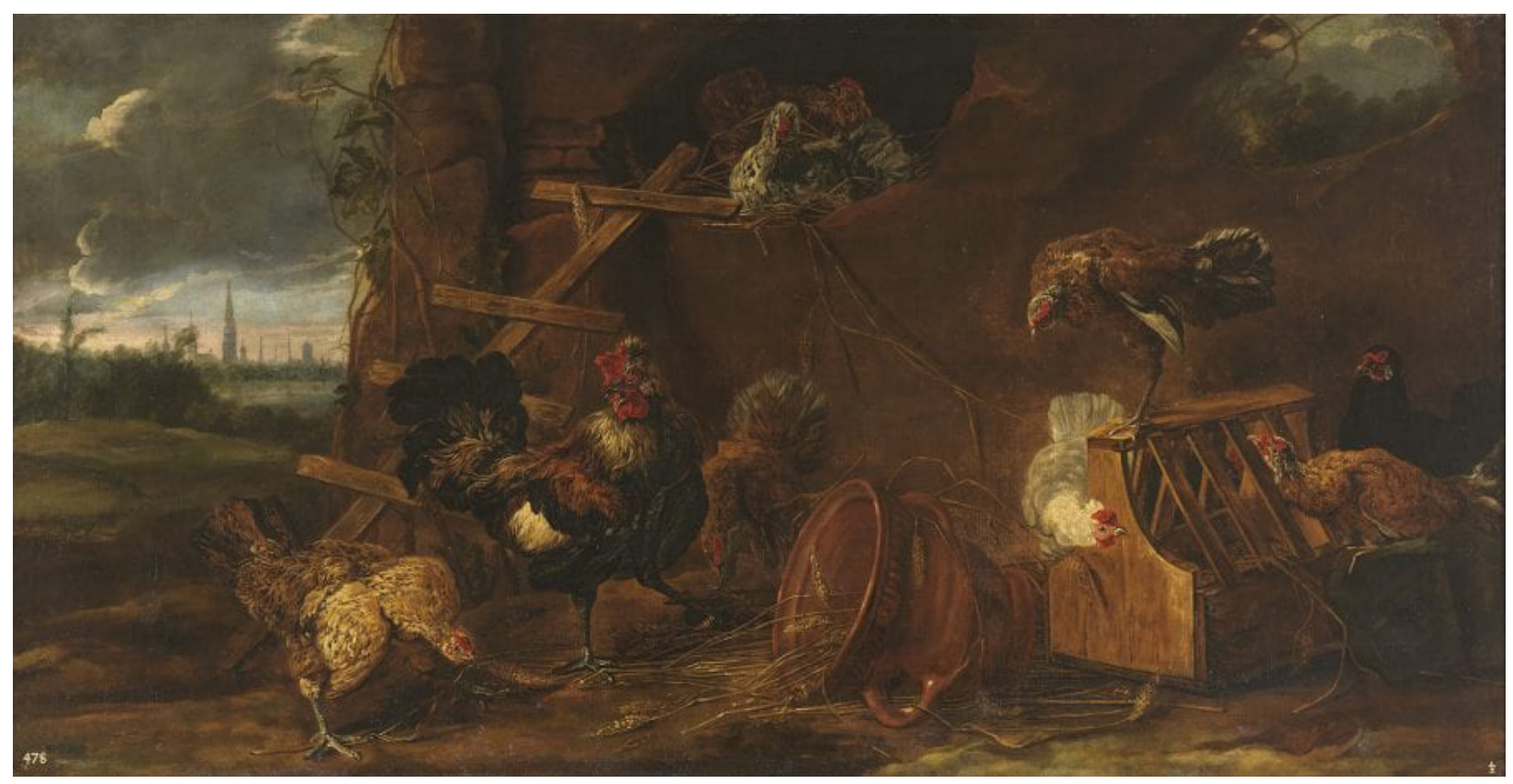

Fig. 1 Joannes Fyt, The Cock and the Jewel ("Gallinero"), 1660, oil on canvas, 123 x 242 cm. Museo Nacional del Prado, Madrid, inv. no. P001526 (artwork in the public domain) Image: Museo Nacional del Prado, 2021

In examining the multiple forms of knowledge that these works address, my argument engages with recent scholarship that has stressed the deep entanglement of art, empirical investigation, and humanistic learning within early modern cultures of inquiry. ${ }^{8}$ Fable imagery, it is true, might seem an unlikely candidate for this line of analysis. Both the conventions of the fable genre, in which animals speak and act anthropomorphically, and its perpetuation of traditional wisdom place it at odds with a modern conception of knowledge that privileges original, objectively established claims. Yet, as William Ashworth, Paul Smith, Katherine Acheson, and others have shown, many of the fable images produced in northern Europe from the 1560s on have strong links to new ways of visualizing the natural world that were being developed at the same 


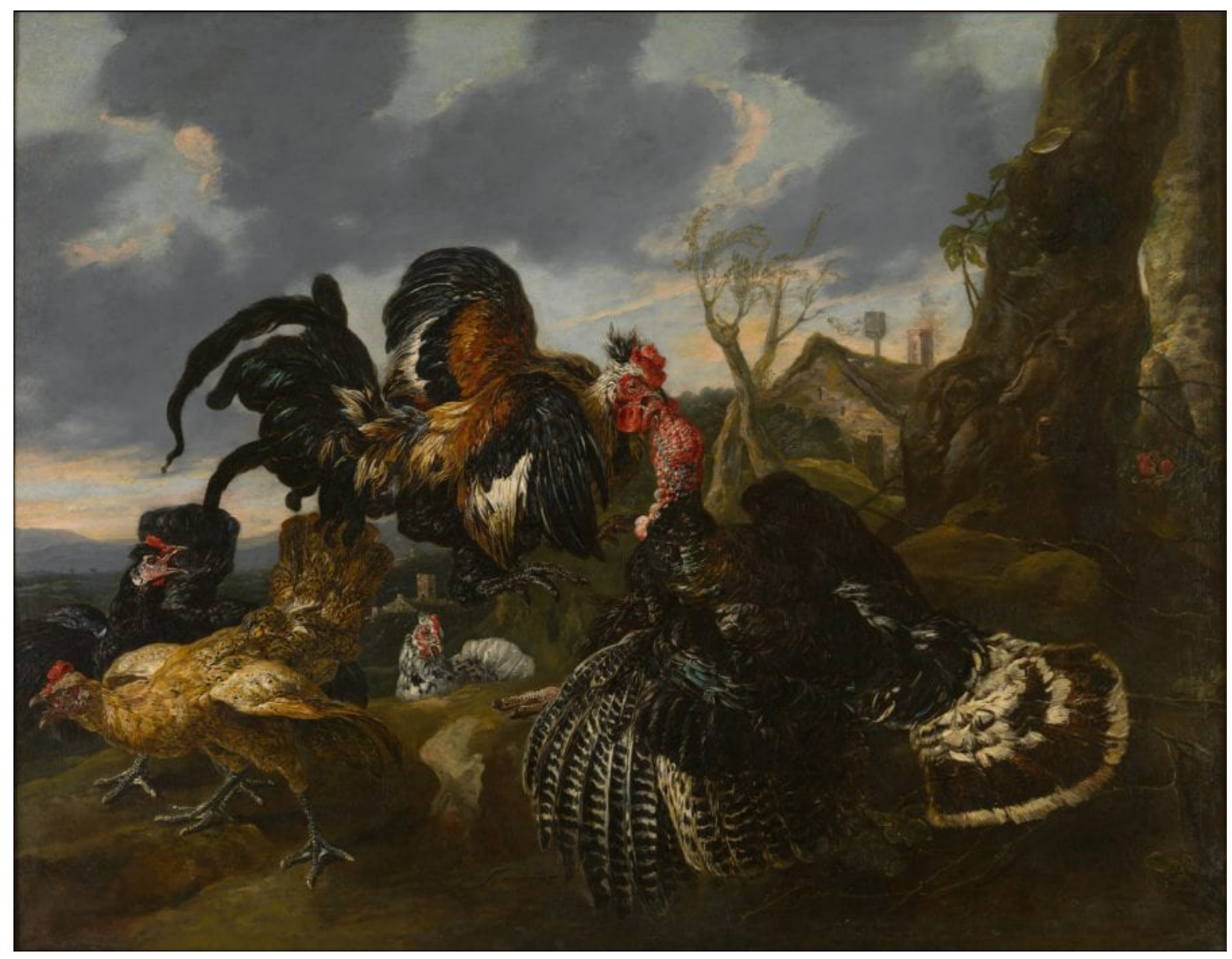

Fig. 2 Joannes Fyt, The Flemish Cock and the Turkey Cock, ca. 1638-61, oil on canvas, 122 x 158 cm. Koninklijke Musea voor Schone Kunsten van België, Brussels, inv. no. 4420. (artwork in the public domain) Image: RMFAB, Brussels. J. Geleyns - Art Photography

time in fields such as natural history and comparative anatomy. ${ }^{9}$ This could certainly extend to fable images featuring poultry birds; although Aristotle had characterized them as earth-bound creatures, being "dust bathing" rather than flighted, they were often discussed and depicted in works by early modern naturalists, for whom they are both aesthetically pleasing and fascinating in their phenotypic diversity. ${ }^{10}$ The Italian naturalist Ulisse Aldrovandi (1522-1605) remarked on their "natural splendour" and "incredible beauty," while the English ornithologist John Ray (1627-1705) noted that "these birds . . vary infinitely in colours" and differ markedly in size and head plumage. ${ }^{11}$

This essay's critical stance also adopts a number of ideas from the strand of ecocriticism called zoopoetics. Originally developed by the literary scholar Aaron Moe to analyze the links between poetic forms and animal sounds and gestures, zoopoetics has since come to designate a range of theoretical approaches united by their framing of the animal as, first and foremost, an embodied, creative, active living being. ${ }^{12}$ Zoopoetics seeks to deconstruct the opposition between the real and the imagined (or "literary") animal, showing how these are at once nonidentical and enmeshed in human thought. ${ }^{13}$ Among the existing varieties of ecocriticism, zoopoetics is particularly pertinent for my discussion because of this nonbinary stance, which challenges the impulse 
to move past the "surface" of the fable image, concerned with material nature, in order to get at something else: a meaning, a moral, a story, or a cache of factual data. ${ }^{14}$ In methodological terms, it also offers a sophisticated model of attentiveness that is helpful in clarifying how the works examined here move between "life" and the world of ideas. ${ }^{15}$ Zoopoetic attentiveness is alert not only to the animal's appearance and other visible traits but also to how it inhabits and actively shapes its environment. ${ }^{16}$ In addition, it is strongly attuned to embodiment-that of the animal and of the human subject. As Eva Hoffmann and Kári Driscoll note, zoopoetics is "a poetics of the body, of the sudden reminder of one's own corporeality and hence of one's own animality." ${ }^{17}$ This aspect of the theory, which modifies the strongly anti-anthropomorphising stance of earlier ecocritical approaches, offers a useful alternative to forms of interpretation that presume an underlying stress on human superiority or exceptionalism in the artwork. ${ }^{18}$

5 Throughout, it will be important to keep in mind that while fable is now seen as a genre that is mainly suitable for children, in Fyt's period it commanded broader and more sophisticated appeal. ${ }^{19}$ Koslow has traced representations of fables by Snyders and artists in his circle to two noble collections in the southern Netherlands (those of the duke of Aerschot and Diego Mexía, marquis of Leganés), in which the works were probably displayed together in series. Flemish fable paintings are also recorded at two Spanish royal residences: ten images by Snyders and de Vos were used as overwindows and overdoors at the Torre de la Parada, a hunting lodge, and a 1701 inventory for the Buen Retiro, a rural palace, lists a further four by Snyders plus others by unnamed artists. ${ }^{20}$ While these works may well have been commissioned by their wealthy collectors, most fable pictures would have been created for the open market and cannot now be linked to specific named beholders. This seems to be the case with Fyt's fables, and for this reason, my contextual analysis of his paintings draws mainly on sources like the Warachige fabulen that were relatively popular and/or were available in the vernacular or Latin, which was widely read among the more educated. ${ }^{21}$

\section{Spotting the Fable in The Cock and the Jewel}

Dated 1660 but unsigned, and currently owned by the Prado, my first example (fig. 1) has been credited to Fyt since it was first recorded as a "Gallinero con Gallinas" (poultry piece with chickens) in the 1746 inventory of the collection of Elisabeth Farnese (1692-1766), wife of Philip V of Spain, at the Royal Palace of La Granja de San Ildefonso. ${ }^{22}$ The attribution to Fyt has recently gained support with the appearance at auction of a smaller signed work that replicates a central section of the composition (fig. 3). ${ }^{23}$ Although the work is first documented in Spain, it was probably originally intended for the Flemish art market. The fact that it does not appear in Spanish royal inventories before 1746 suggests that it entered the country during the extensive campaign of picture buying undertaken by Philip and Elisabeth from the 1720s on, partly to decorate their new palace of La Granja, which was begun in $1721 .{ }^{24}$ In his lifetime, Fyt had few Spanish buyers; Antwerp was his primary market, and the appearance of the city's skyline in the left background of the composition seems to address the picture to a local audience there. ${ }^{25}$

At almost two and a half meters wide, the Gallinero is one of Fyt's largest paintings. It is thus initially surprising that it focuses on what appears to be a very humble scene. On a rough dirt track, ten birds stand, nest, or forage for food. The most prominent of these is the black and gold 


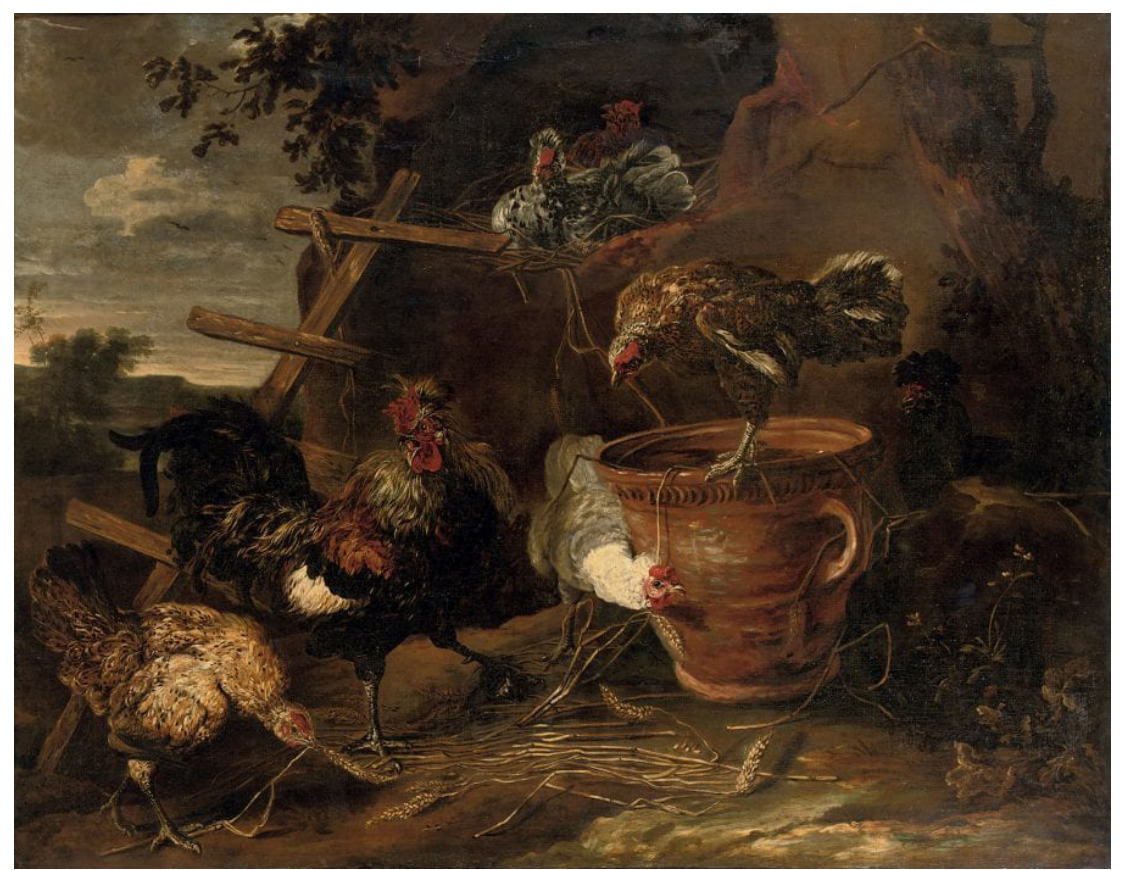

Fig. 3 Joannes Fyt, The Cock and the Jewel, ca. $1638-61$, oil on canvas, $118.8 \times 153$ cm. Sold at Christie's, Amsterdam, April 13, 2010, lot 78. (artwork in the public domain) Image: Christie's

cock in the foreground. With one foot planted, he scratches with the other at a dark patch of soil strewn with grain stalks. On either side of the cock, their crouching stance underscoring his upright bearing, two hens bend their heads to the earth as if searching for food. Off to the right, beyond a toppled terracotta pot, five more hens encircle a wooden feed-box. A gold hen and a black hen at far right glance up and across at the brown hen perched on top of the feed-box. This bird peers down at a white hen who is nosing around the left-hand end of the box, craning her neck as if eager to catch a glimpse of her companions a short distance away. In a wall overlooking the site, two hens nest in an oval hollow. A ladder leads from their roost to the dirt track below.

A closer look at the painting reveals an important detail that broadens the interpretative response it demands. This is the jeweled ring beneath the cock's leading foot (fig. 4), which signals an allusion to the Aesopic fable called The Cock and the Jewel. ${ }^{26}$ Upon finding a jewel (when named, usually a diamond, ruby, pearl, or a ring) while pecking in his straw for food, the cock declares that although it would be of great value to some people, it is of no use to him; he would prefer grains of corn or barley to eat. In the fable book tradition, this simple narrative is often interpreted as a condemnation of ignorance or materialism, failings embodied by the cock, who chooses transient bodily sustenance over the jewel, an object of lasting value. ${ }^{27}$ Unlike grain, however, a jewel cannot sustain life. Accordingly, alternative readings of the fable existed in which the pragmatism of the cock in preferring something useful over something showy, or his acuteness in noticing the jewel, are praised instead of censured. The Cock and the Jewel was evidently a popular fable in the Netherland ${ }^{28}$ and may even have entered common language as a figure of speech, given its appearance in the 1603 Dutch translation of a conversation manual, where it demonstrates the differences between ignorant and learned people. ${ }^{29}$

9 A broad range of interpretations of the fable can be found in the major vernacular fable collections available to Netherlandish readers in Fyt's day. The moral accompanying the fable in the 


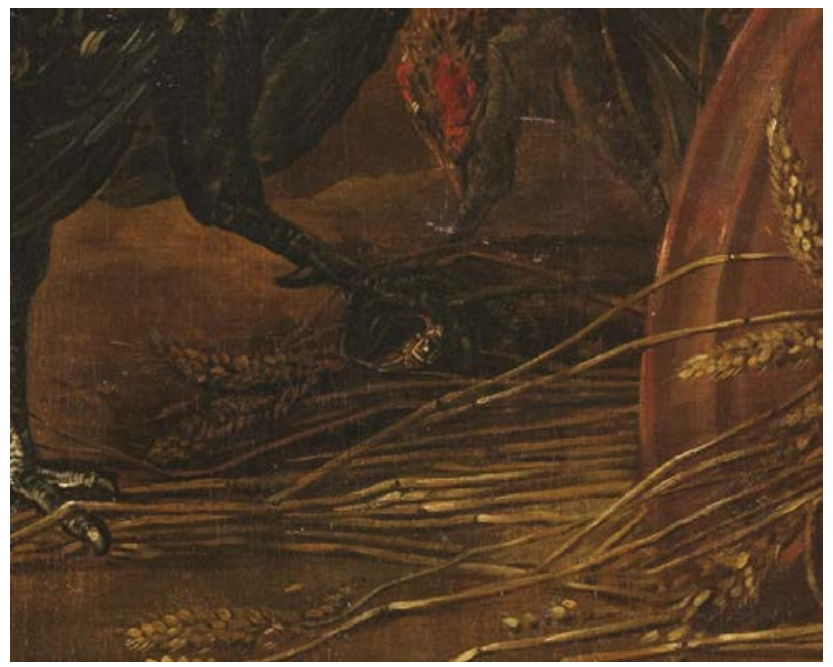

Fig. 4 Joannes Fyt, The Cock and the Jewel ("Gallinero") (fig. 1), detail. Image: Museo Nacional del Prado, 2021

Warachtige fabulen specifically deprecates spiritual blindness. De Dene describes the cock's attitude toward the jewel- "For that which one has no use for, one cares very little"-before noting its possible application to human behaviour:

Likewise those people who are of a worldly disposition and adrift, who instead of spirit choose things of flesh and blood, who scrape around in the earth most of the time, and are meticulous and grasping in their attitude to material goods; this is terrible and does a lot of harm-and quickly; they tread knowledge and wisdom under foot, and also put God entirely aside, leaving brightness lying on the side. ${ }^{30}$

A more multifaceted interpretation is offered in the Vorstelijcke Warande der Dieren, a popular 1617 adaptation of the Warachtige fabulen by the Dutch poet Joost van den Vondel (1587-1679). He initially follows de Dene in presenting the fable as a condemnation of those who value worldly things excessively-although here the cock, because he rejects the "pearl" (as the jewel is called in this text), represents spiritual wisdom rather than blindness. Immediately, however, the poet goes on to note that the pearl "is also the knowledge [konst] possessed by the wise and learned," which the "unwitting cock" passes over:

O Crowned, wise bird! Would that you could teach your betters to despise and scorn their lascivious friskiness and costly flaunting. Thus will you convert men and yet reflect to them your ostentation and pride. The pearl is also the knowledge of the wise and the learned which the unwitting cock neglected and scorned: Superficiality is a jewel of no value if you lack inward humility. ${ }^{31}$

11 Notable here is the variety and incongruity of the significations proposed in just these two texts. The cock is seen as wise as well as ignorant, and in other fable books even figures as an embodiment of diligence, owing to his success in finding the ring. ${ }^{32}$ 
This more positive characterization of the animal was well known, appearing in emblematic and encyclopedic works as well as fable books. In the 1644 Dutch translation of Cesare Ripa's influential emblem book, the Iconologia (1593), the cock appears in the emblem for "Diligenza." The text characterizes the animal as "careful," noting that "in [his] scraping and searching [he] shows great diligence, even when he finds nothing pleasing to him, distinguishing also the useless grains from the useful, which represent value and food for him." ${ }^{33}$ Aldrovandi, whose works were known to Snyders (and thus very possibly also to his associate Fyt), mentions the animal's connection to the careful, scrupulous merchant via his role as an attribute of Mercury, god of trade. ${ }^{34}$ He cites in support of this a proverb by the Latin poet Ausonius known as "The Rooster of Eucleo," applicable to the person "who is accustomed to examine and investigate everything most diligently, not even neglecting the slightest dust until he has found that which he has searched for with the utmost care." 35

The complexity of the fable's interpretative tradition is of interest when Fyt's adaptation is placed in its art-historical context. There are only two major precedents for the painting, both linked to Snyders: an undated work by the older artist that was probably produced in the 1620s and is now in Aachen (fig. 5), and a workshop picture that was sold on the London art market in 2001 and was originally in the collection of Thomas, 1st Earl Coningsby (1656-1729) at Hampton Court, Herefordshire (fig. 6) ${ }^{36}$ Both closely follow the model supplied by Gheeraerts in his etching for the fable in the Warachtige fabulen (fig. 7). ${ }^{37}$ This is particularly true of the Aachen painting, in which, as in the print, the cock is depicted alone. In the workshop picture, additional interest is provided by the wide format and supplementary hens (ideas that Fyt may have borrowed for his treatment of the fable), but its depiction of the cock is, again, similar to that in the etching. Both these works are also immediately identifiable as fable paintings given the prominence they

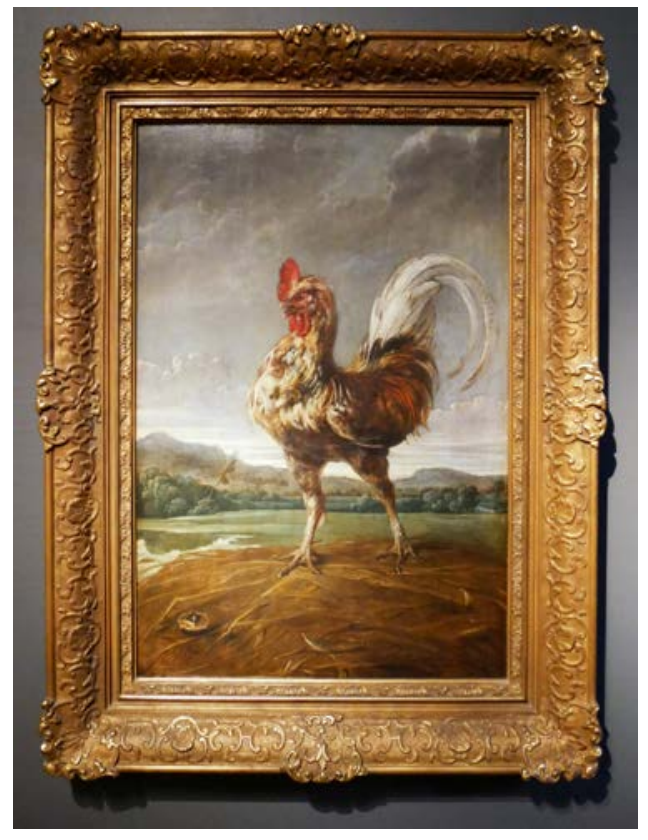

Fig. 5 Frans Snyders, The Cock and the Jewel, ca. 1616-20, oil on panel, $100 \times 67 \mathrm{~cm}$. Suermondt-Ludwig-Museum, Aachen, inv. no. 484 (artwork in the public domain)

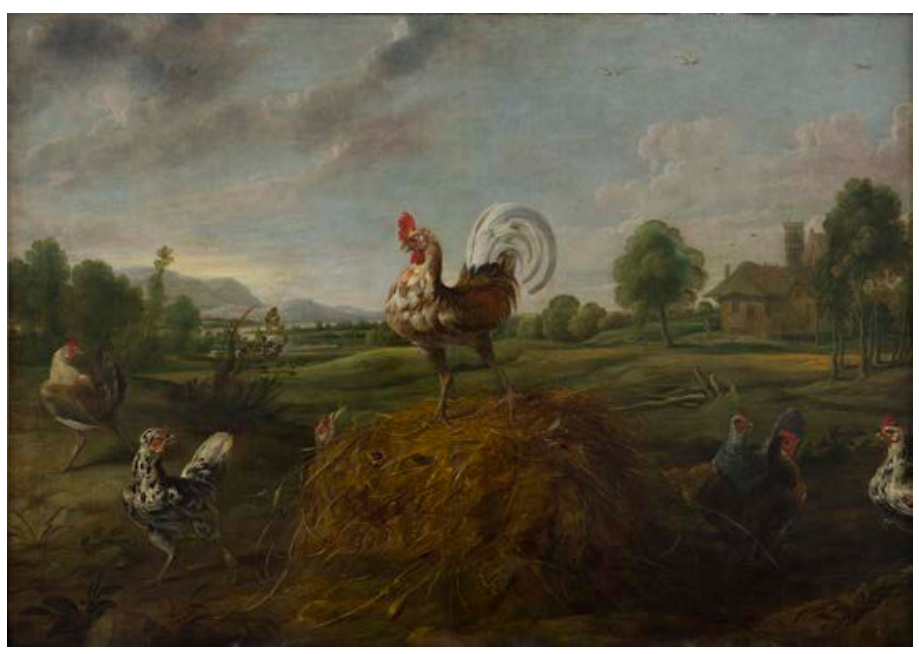

Fig. 6 Workshop of Frans Snyders, The Cock and the Jewel, ca. 1620, oil on canvas, $169 x$ $240 \mathrm{~cm}$. Auckland Art Gallery, inv. no. 2016/21 (loan). (artwork in the public domain) Image: Auckland Art Gallery Toi o Tāmaki, NZ 


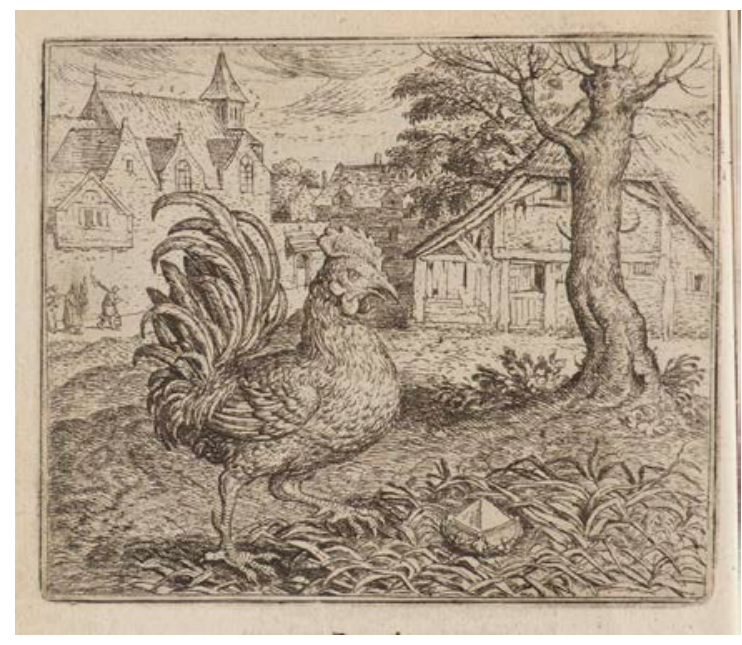

Fig. 7 Marcus Gheeraerts, "Den Hane op den messijnk” (The Cock on the dung hill), in Edewaerd de Dene, De warachtighe fabulen der dieren (Bruges: P. de Clerck, 1567), 46. (artwork in the public domain) Image: BNF, Paris

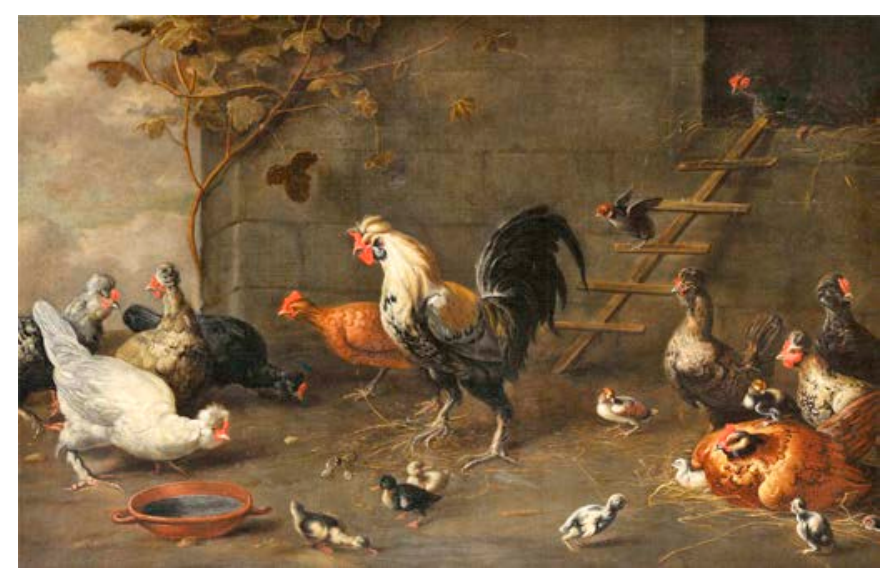

Fig. 8 Melchior de Hondecoeter (attrib.), The Cock and the Jewel, ca. 1670-99, oil on canvas, $121.9 \times 165.1 \mathrm{~cm}$. Powis Castle, Powys, inv. no. 1180965. (artwork in the public domain) Image: National Trust Images [side-by-side viewer]

accord to the jewel: a red gem in a gold setting. A later adaptation of the fable, undated but probably produced at around the same time as or after Fyt's (fig. 8), similarly situates the jewel in a discrete, uncluttered space where it is clearly visible. ${ }^{38}$

14 What emerges from these comparisons is that in Fyt's Gallinero, more so than in adaptations of the fable by other artists, the fable coexists with a rich visual account of different avian behaviours and responses, not all of which can be linked directly to the narrative of The Cock and the Jewel or its usual moralizations. While the work would certainly have been legible as a fable painting, it is important not to gloss over the fact that it treats its subject in this rather expansive way, and that this produces a degree of interpretative uncertainty. On the one hand, the fable/ ring is perfectly visible if this large painting is examined reasonably carefully, and both the familiarity of the fable and the circulation of fable books containing illustrations of The Cock and the Jewel may well have primed beholders to look for a jewel in a work of this kind. On the other hand, the allusion to fable is less explicit than in other versions. Significantly, no reference to it can be found in the eighteenth-century Spanish inventories in which the work was first recorded, although it was evidently still valued as a "poultry piece" that skillfully depicts avian life.

Viewing the painting through a zoopoetic lens cannot wholly resolve these tensions. However, it does allow us to see the different currents in the Gallinero as mutually reinforcing aspects of a praiseworthy attentiveness to nature that is attributed both to the artist and to the picture's beholder. As Moe has argued, "an attentive disposition precedes imitation"; from a zoopoetic perspective, skilled imitation is not an exceptional faculty restricted to the artist, but it instead originates in the sensitive, vigilant response to the world that all living creatures, whether human or animal, display. ${ }^{39}$ Given that major themes of the fable as depicted in the Gallinero are the perception of value and the value of (visual) perceptiveness, it is thus significant that the work's composition contains points of interest that reward the experience of viewing it carefully. These include the glittering eye visible between the bars of the feed-box that reveals the presence of an additional black hen in the right-hand group (fig. 1), and the individuated grain sheaves in the 
foreground, itemized so carefully that their stalks and ears can be counted. These bring the attentive painter and the attentive cock into alignment, presenting Fyt as an artist who, like the man in Ausonius's proverb about the bird, is willing "to examine and investigate everything most diligently," even the smallest ear of grain. In the case of the attentive beholder who notices the ring, a further parallel emerges between the event that drives the plot of the fable-the cock's fortuitous spotting of the jewel-and the type of gaze that the painting encourages, in which noticing details is important as well as a source of pleasure and interest. Wittily revising the idea, mentioned in most textual versions of the fable, that earthly things should be rejected, the Gallinero asserts the value of skillful engagement with the material world, whether performed by the artist or an alert beholder. ${ }^{40}$

In the case of the animals, this attentive disposition extends to how they inhabit their environment. Consistent with premodern ideas about the need for human stewardship of nature, the painting implies that the birds' existence has been enabled by benevolent human dominion. ${ }^{41}$ Readers familiar with the chapters in the works of naturalists such as Aldrovandi and Conrad Gessner on how to rear and house poultry, or the classical accounts they summarize, would have noted points of correspondence with the work. Grain, identified by Aldrovandi as the best possible food for the birds, is what they have been given to eat, and they have also been granted easy access to the nesting hole in line with his advice that outside the roost "little ladders should . . be joined to the wall on which the birds may creep to their nightly rest." ${ }^{42}$ In his description of the outdoor chicken run, Gessner notes that it should be open to the sun and sheltered from the wind and cold so as to keep the birds warm (conditions met by the screened space in the painting), and he recommends hollowing out small nests in a nearby wall to encourage egg laying. ${ }^{43}$ As mentioned previously, works by Aldrovandi were known in Snyders's circle, and so it is quite possible that Fyt had gained knowledge, perhaps on a secondhand basis, about the ideas in these and similar texts relating to best practices in raising poultry. The crucial point, however, is that the painting could have been appreciated for its grasp of these down-to-earth matters as well as for the abstract ethical ideas linked to the fable that it conveys through their representation.

17 Naturalists also comment on another topic relevant to the themes of the picture: the visual and sensory faculties of poultry birds. The advanced perceptual powers of the typical cock are repeatedly identified as one of its defining traits. Aldrovandi notes his "exquisite sense of taste" which allows him to "judge on the spot any object ... if only he can hold it in his mouth." ${ }^{44}$ Also, the cock "possesses no small keenness of sight," being able to make out predators from a distance, and even surpasses the eagle both in sharpness of vision and in having the ability to dedicate each eye to a separate task:

with only one eye always turned upwards [the cock] observes the birds of prey which are its most deadly enemies lest they unexpectedly snatch away either a chick or a hen or the rooster himself out of the chicken yard, while with the other eye he most diligently examines very small things. ${ }^{45}$

In contrast to later models of symbolism that propose an arbitrary relationship between referent and idea, here the visual acuity of the real animal is linked to (and implicitly validates) his associ- 
ation with the abstract concepts of diligence and vigilance. ${ }^{46}$

19 The Gallinero, similarly, moves between storytelling, allegory, and the lifelike depiction of real-world phenomena in a manner likely to have been appreciated by Fyt's audience. In the discussion of the value of fable in Erasmus of Rotterdam's influential rhetorical handbook De Utraque Verborum ac Rerum Copia (On Copia of Words and Ideas), better known as De Copia (1512), it is precisely this combination of creativity and keen attentiveness to the real world that is recommended. ${ }^{47}$ In the book's main treatment of fable, Erasmus begins by noting its attractions for the reader (including its vividness and its capacity to provide a witty commentary on human behavior), before turning to the question of how to compose a fable:

Each person is perfectly at liberty to invent material [fables] of this sort, according to his subject, but if you are going to invent something appropriate, you need to be a person of lively imagination and you must have observed closely the nature of living creatures, and these are of infinite variety. ${ }^{48}$

Elsewhere in De Copia, Erasmus again remarks: “There are appropriate characteristics to be observed in fables, and this no one will be able to manage unless he has observed and studied the natures of living creatures," following this up with several examples: "All this, and less well-known facts too," he notes, "may be easily discovered in Aristotle, Pliny, and Aelian." ${ }^{49}$ In Erasmus's conception of fable, then, which resonates with a zoopoetic stance, the bodily and instinctual character of the animal should leave its trace in the text, rather than being expunged in order to turn the animal into a "character" unrelated to its real-world counterpart. The fable writer, moreover, should aim to capture the natures - not simply the contingent appearances or behaviors-of the creatures he is concerned with, relying if necessary on encyclopedic sources like Pliny's Natural History to supplement his own experience.

21 These ideas might well have provided a way for contemporary beholders of Fyt's work to comprehend his detailed attention to animals and their environment: as evidence of his ability to imbue Aesopic narratives with a sure grasp of living nature. This aspect of the work might even have been understood as a form of pictorial copia that wittily expands upon and embroiders around the main topic of the picture - the fable-to hint at what Erasmus calls the "infinite variety" of nature. The birds in the painting emerge as a vital point of intersection, being at once objects of study, sources of visual fascination, and beings which, though in a different way to the human, exhibit volition and agency.

\section{Of Kin and Kind in The Flemish Cock and the Turkey Cock}

22 Engagement with the diversity of avian life is also crucial to my second example, The Flemish Cock and the Turkey Cock, in which the variation between species underpins a fable about the ethical, political, and ecopolitical significance of sharing a dwelling place. Signed "Joannes Fyt" at lower left and dateable on stylistic grounds to the mid-1650s, only a single version of the painting, now in the Koninklijke Musea voor Schone Kunsten von België, Brussels (fig. 2), is known. 
Important precedents for the picture are the depictions of bird fighting that became popular in the Netherlands from the $1610 \mathrm{~s}^{50}$ The attraction of such works can in turn be connected to an interest in the sport of cock fighting, ${ }^{51}$ which despite being condemned by moralists was practiced by elites as well as commoners. ${ }^{52}$ Avian violence certainly seems to be one of the attractions of the painting discussed here. A large black and gold cock has leapt into the air in order to grasp the head of another bird with his beak. White highlights on the talons and spurs of the cock's right leg call attention to their bony sharpness. The victim of the assault has been completely overpowered: he reels backward, two of his toes splaying out limply beneath his wing. At left, smaller birds flee the struggle or observe from a distance.

Though superficially similar to depictions of fighting cocks, the Brussels painting responds to a separate literary tradition. The victim of the cock's attack is a turkey, identifiable by its nodular head and its snood-the red wattles beside its eyes. A new fable invented by de Dene, "De Vlaemsche ende Turcksche Haen" (The Flemish Cock and the Turkey/Turkish Cock), appeared for the first time in the Warachtige fabulen and was quickly incorporated into later adaptations of the book..$^{53}$ In the fable, a turkey moves into the territory of a conceited cock, and his courteous behaviour immediately endears him to the local hens. Enraged at this incursion, the cock begins a campaign of violence against the turkey. When the turkey sees that his skirmishes with the cock are frightening the younger birds, he magnanimously decides to find a new home. In Fyt's adaptation, careful attention to the gestures and appearances of individual birds-evident, for example, in the twisted poses of the scattering hens on the left, whose open mouths indicate that they are shrieking - showcases his knowledge of nature while also bringing de Dene's fable to life. Dispensing with the rigid profile view of Gheeraerts's original etching (fig. 9), Fyt allows the birds to dominate the pictorial space-especially the fighters, who are depicted in dynamic combat and situated in a barren landscape setting different from that seen in versions of the fable by other Antwerp painters (figs. 10-11). Fyt's skill in depicting varied, lifelike animal bodies in lively movement is noted by Cornelis de Bie (1627-ca. 1715), a biographer of Dutch and Flemish artists, suggesting that these same qualities in the work would have been regarded positively in the artist's day. ${ }^{54}$

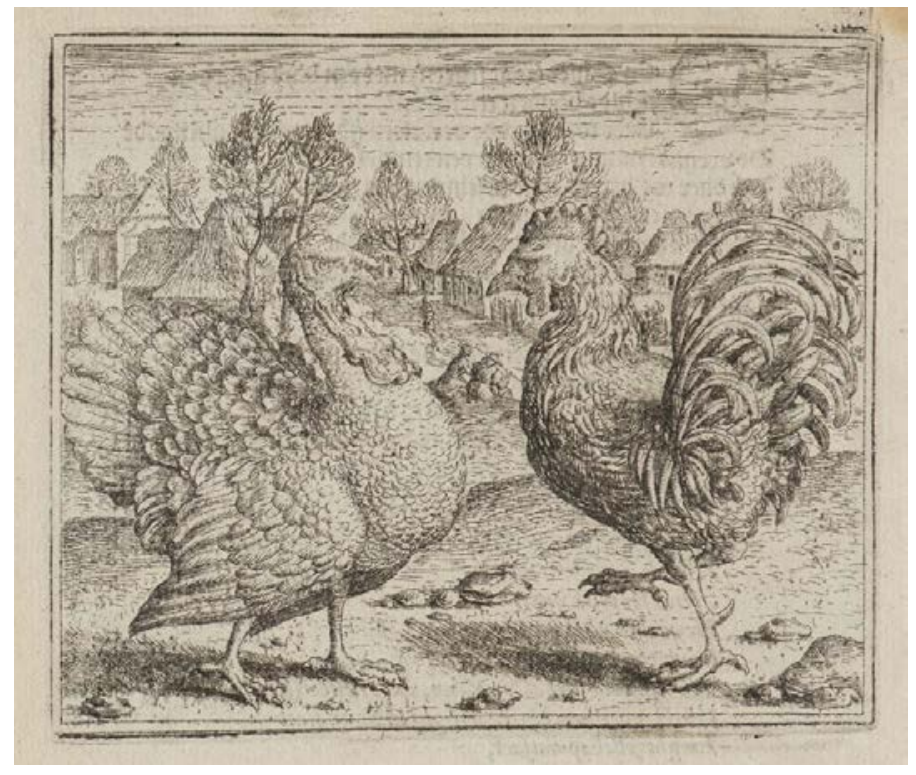

Fig. 9 Marcus Gheeraerts, "Vlaemsche ende Turcksche Hane" (The Flemish Cock and the Turkey (ock), in Edewaerd de Dene, De warachtighe fabulen der dieren (Bruges: P. de Clerck, 1567), 190. (artwork in the public domain) Image: BNF, Paris 


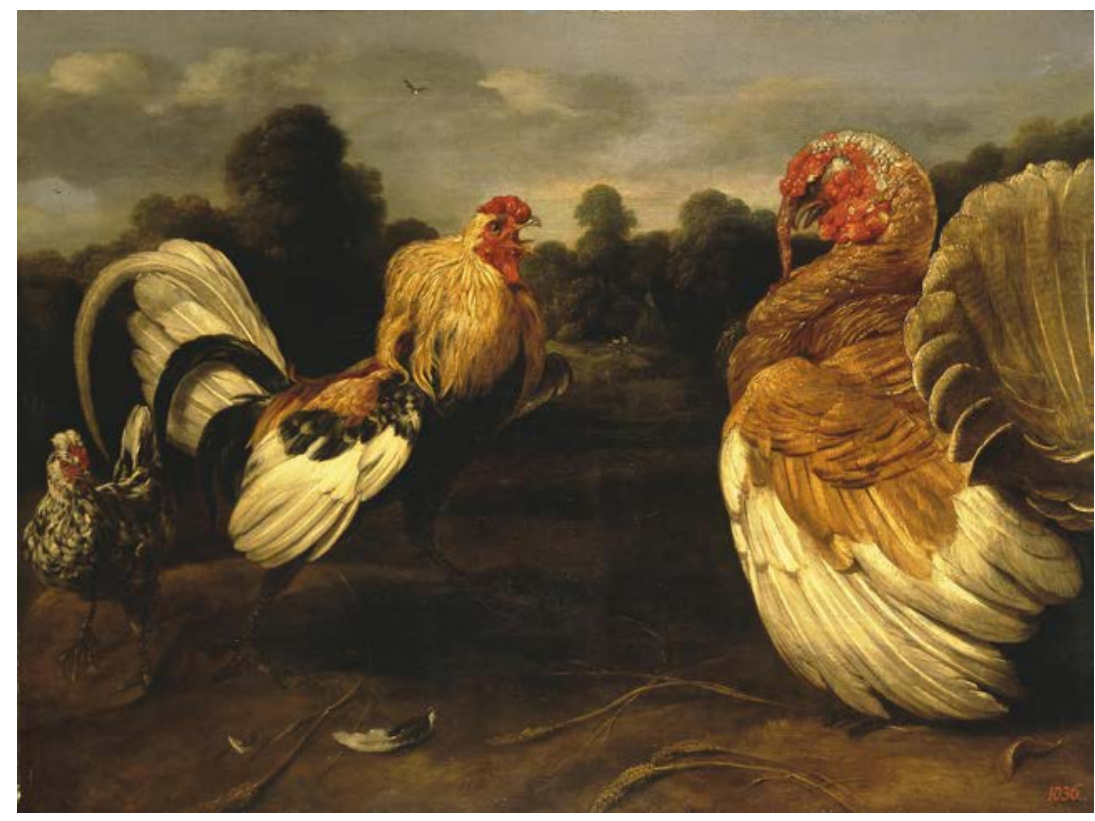

Fig. 10 Frans Snyders, The Flemish Cock and the Turkey Cock, ca. 1650-57, oil on canvas, 88.5 x $118.5 \mathrm{~cm}$. Hermitage Museum, Saint Petersburg, inv. no. 655 (artwork in the public domain) Image: Hermitage Museum, Saint Petersburg

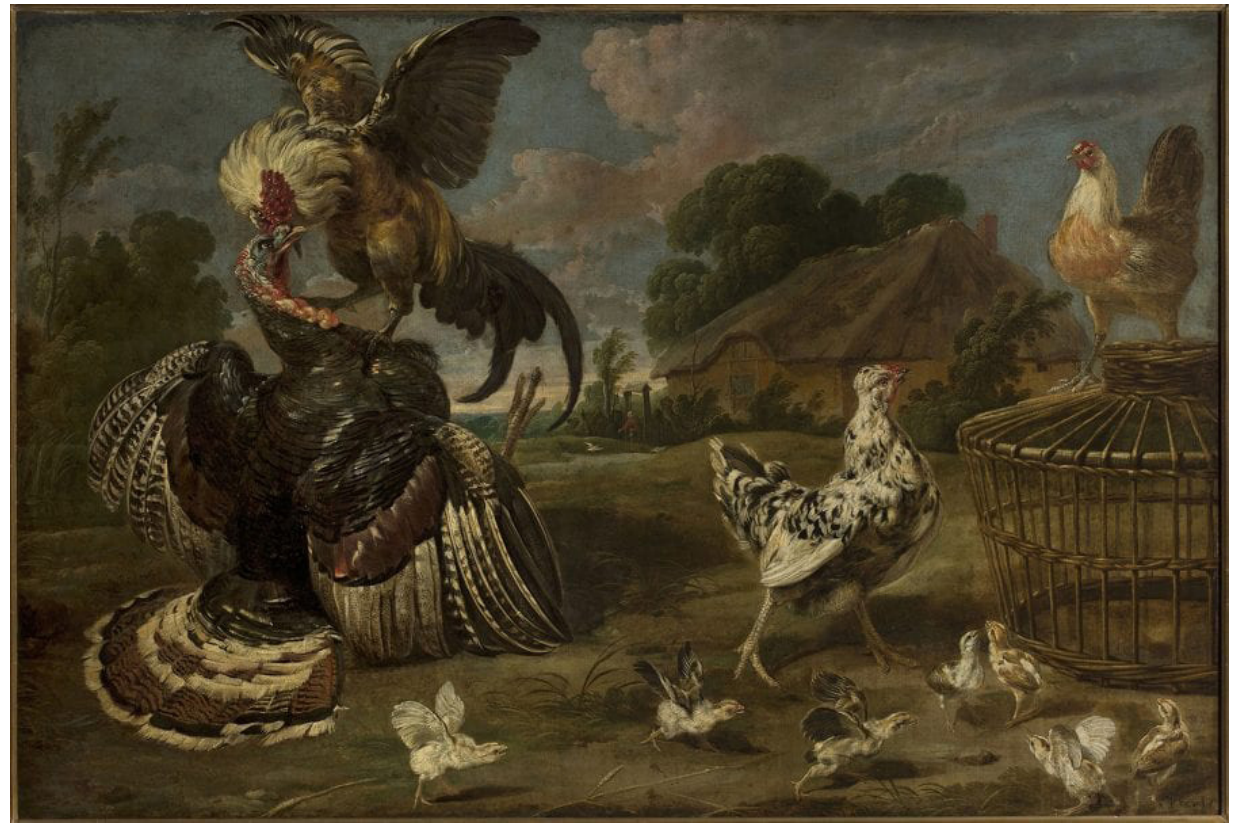

Fig. 11 Paul de Vos, The Flemish Cock and the Turkey Cock, ca. 1615-78, oil on canvas, $122 \mathrm{x}$ $185.5 \mathrm{~cm}$. Muzeum Narodowe, Warsaw, inv. no. M.0b.2504. (artwork in the public domain) Image: National Museum, Warsaw

24 Despite the cock's dominant position in Fyt's Brussels painting, the moralizations in Flemish fable books make clear that he is the villain of the fable. His selfish attitude is interpreted in these texts as a denunciation of those who are intolerant toward strangers who come to live among them. In Vondel's moralization, this extends to a condemnation of "savage" xenophobic attitudes:

In the end the Turkey saw that the Dutch cock would leave him neither rest nor peace: so he removed himself completely from all kinds of strife, and chose to seek his daily bread in peace in other places. "Many peoples are so wild, so savage and hot headed, that the poor stranger may not dwell with them. Even though they have won a land for their own needs, they would even begrudge another to live on the very 
earth itself." 55

25 De Dene's original fable had underscored equally strongly the roles of the cock and turkey as, respectively, native dweller and stranger by its designation of the birds as a "Flemish" and a "Turkish" or "foreign" ( $d$ 'Wytlandtsche) cock—categories that imply difference but also common membership of a wider, overarching type. ${ }^{56}$ In his moralization, de Dene, like Vondel, takes the xenophobic to task: "Likewise, some take the view that a foreign visitor should accept duress just to be allowed to live; they mumble jealously among themselves, not resting until they have driven him out." 57

26 The error of judgment that leads the proud cock to commit violence is thus not a mistaken characterization of its victim as entirely "Other," an animal deserving his scorn because it is different from him. The cock's recognition of the turkey as a potential competitor in the mating game also acknowledges similarity between them. This is a point made explicitly in the opening line of Arthur Golding's contemporaneous English version of the fable: "A DUNGHILL Cock being of a proud courage, stood so immoderately in his own conceit that he disdained all fowls of his own kind." 58

27 Introduced into the Netherlands in the sixteenth century from the New World, the turkey had initially been viewed as an exotic, with the matter of its species relationship to the cock stimulating much debate. Initial discussions of it by early modern ornithologists are a morass of confusion, with it being mistaken for the peacock, guinea fowl, and varieties of poultry from the Indian subcontinent, among other birds. However, as Lise Lotte Möller has shown in her survey of visual depictions of the turkey, by the beginning of the seventeenth century its presence in Europe was well established. ${ }^{59}$ Seen from the point of view of up-to-date natural history, therefore, the cock's error is a double one: he not only perpetrates illegitimate violence but does so against an animal to which he is in some sense related and who has a legitimate claim to share his dwelling place. ${ }^{60}$

28 Questions about the difference between closely related kin had particular relevance to the Low Countries, a dwelling place that was also an unstable, contested territory. De Dene's new fable about two birds of the same kind but different "nationalities" would have carried multifaceted political resonances for readers in the southern Netherlands living through the 1560 s and later decades, when the question of who should be able to inhabit the region had become divisive. ${ }^{61}$ The fable might have been taken to refer to the ongoing military conflict with the northern provinces, which were previously firmly under the control of the Spanish Habsburg empire, or to the often fractious relationship between the Flemish themselves and their Spanish overlords. Given the continuing popularity of fable books, Fyt's later painting is likely to have retained much of the fable's original political charge. Although in 1648 the seven northern provinces were officially recognized by Spain as a separate geopolitical entity, inhabitants of the whole region, particularly those in towns and cities situated along the shifting border between north and south, continued to suffer the effects of military conflict throughout much of the seventeenth century. By the middle decades of the century, too, the opportunities and risks associated with dealing with the Turk, or foreigner, and with the New World (still regarded at this point as the turkey's place of origin) 
were at the forefront of national attention.

29 While individual beholders might have identified the birds in the Brussels painting with one or another of these forces, fundamentally the politics of the work has more to do with how it negotiates a deeper, longstanding anxiety in the culture about how to integrate and transact with the Other (however defined) without a fatal loss of one's own power, identity, or physical territory. Fyt's intensely vitalized rendering of the opposing factions in the painting as battling, rapidly moving bodies allows the uncertainties that surrounded this issue to manifest themselves visually. For example, the tension between the birds' current hostility and their underlying kinship is registered in the way that their fighting forms are echoed in the two gnarled trees growing around each other behind them - an image of separateness that also hints at the possibility of imminent reunion or future coexistence. Calling to mind the idea in zoopoetics that the creature and its habitat exist in continuous interchange, this visual repetition also collapses the boundary between the birds' desperate struggle and the barren environment they occupy, linking the problem of intolerance to its deadening impact on the homeland.

30 The painting offers a counterpoint to this negative vision of internecine violence, although its inclusion is subtle and-in a parallel to the Gallinero-requires close attention to be noticed. The structure attached by a post to the roof of the farmhouse in the far distance is a dovecote. Discernible as white marks that stand out against the building behind them, several doves can be seen (fig. 12). Breeding these birds was a pastime of the affluent; as such, the inclusion of the dovecote identifies the territory in the background as a wealthy Flemish estate. However, when taken together with the fight in the foreground, the signification of the dove as a herald of peace, via its association with the Holy Spirit, also comes into play.

31 The inclusion of the dovecote sharpens the division between the foreground and background zones of the painting. A traditional humanistic reading of the work would tend to map this pictorial splitting onto an anthropocentric hierarchy, with the background interpreted as the

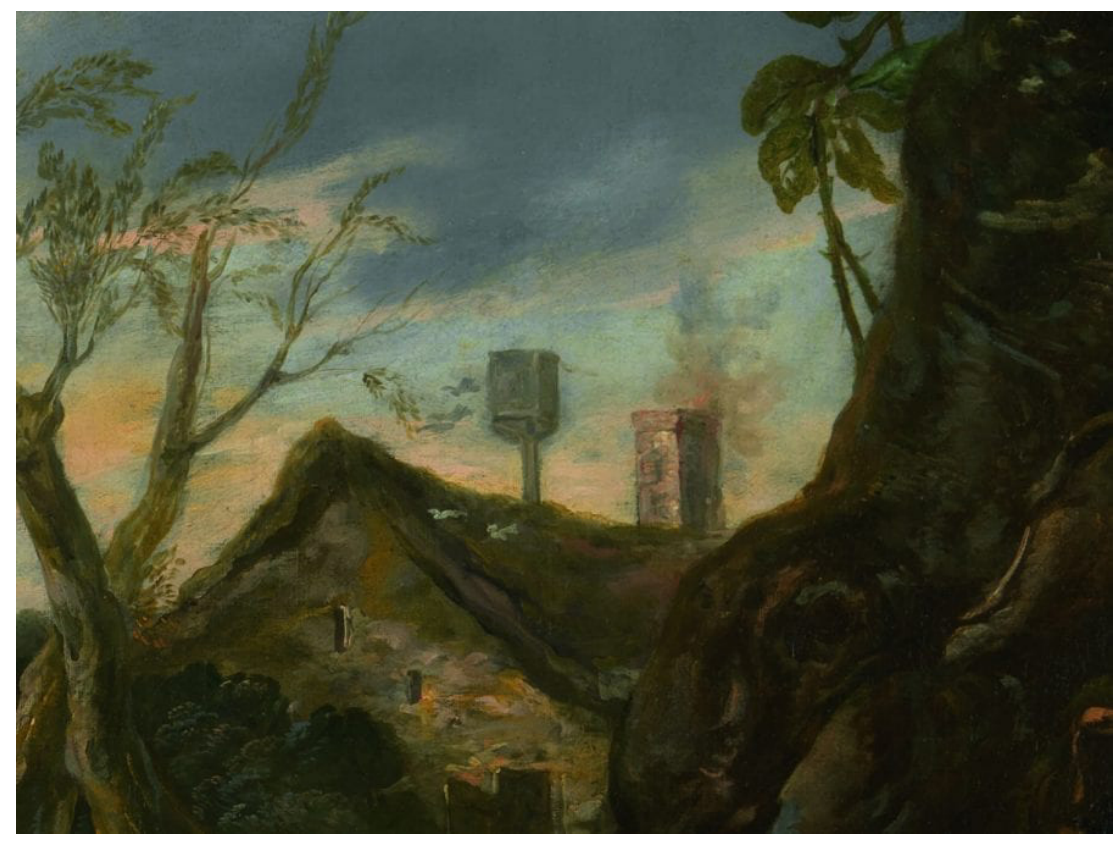

Fig. 12 Joannes Fyt, The Flemish Cock and the Turkey Cock (fig. 2), detail. Image: RMFAB, Brussels. J. Geleyns - Art Photography 
space of the civilized human being (seen as the antithesis of the cock because, as the dovecote indicates, he is willing to share his dwelling place with the Other), which is then juxtaposed with the animal violence occurring in the foreground. In calling attention to the embodied character of the human gaze, zoopoetics can productively complicate such a reading. It asks that we also take account of the painting's capacity to generate an excited, engrossed reaction to the spectacle of violence, belying the view that incivility is restricted to the animal Other. In place of a cohesive moral subject that rejects violence, zoopoetics points to a more equivocal construction of human nature in the work-one divided between the pacific, elite subjectivity in the background and a "lower," more voyeuristic mode of looking produced by the work's close viewpoint, which brings the beholder near enough to the struggle to see that the cock has seized the turkey by its snood. Like the depictions of bird fighting to which it is related, the painting negotiates the ambivalences that attached to witnessing avian violence, which in the period had less to do with concerns over animal suffering than with acknowledging the savage or animalistic side of human nature and its potentially disastrous social effects.

\section{Conclusion}

The rise in northern Europe of fable pictures that pay unprecedented attention to the variety and complexity of birds' bodies, temperaments, and abilities, first in printed books like the Warachtige fabulen and later in the easel format, took place at a moment when images had begun to play an increasingly vital role in the production of knowledge about animals and the nonhuman environment. In an era before the disciplinary divide between factually based and imaginative ways of understanding the material world had become fully entrenched, fable texts and images aligned new discoveries about nature with bodies of classical, scholastic, and humanistic knowledge that were still widely regarded as authoritative. In this essay, I have argued that Fyt's fable painting can be understood usefully within this framework. In the works examined here, the description of nature does not take precedence over the engagement with fable. Rather, the narrative, allegorical, lifelike, and "factual" aspects of the image exist in an interplay that resists being disaggregated. The Gallinero is centrally concerned with a form of visual acuity, linked to the diligent, scrupulous cock, that is presented as worthy of emulation-something that plays against the emphasis in many versions of the fable on the difference between ignorant animal and knowing human. Challenging the beholder differently, the Brussels painting asks us to attend to a spectacle of violence that places side by side harmful aspects of animal and human nature, in particular their capacity for violence and intolerance. Both works evade singular categorization as either animal paintings or fable paintings, and they operate across what would later become the "two cultures" of art and science at a moment before their definitive separation.

\section{Acknowledgements}

I am grateful to the reviewers, to reading groups at the Courtauld Institute of Art and the University of Edinburgh, and to Jill Burke, John Chu, Naomi Lebens, Emily Mann, Kirsty Stewart, Piotr Stolarski, Joanna Woodall, and Alice Zamboni for comments on this essay. Thanks are also due to Bethan Tovey for assistance with some translations. 
Thomas Balfe received his PhD from the Courtauld Institute of Art, University of London. He is an art historian specialising in Flemish easel painting and graphic art, c.1550-c.1750. His research areas are animal, hunting, fable, food and human-animal inversion imagery, and vocabularies of lifelikeness in early modern art writing. He recently completed a Teaching Fellowship (History of Art) at the University of Edinburgh. His co-edited book on the term ad vivum and its relation to images made from or after the life was published by Brill in 2019.

thomas.balfe@courtauld.ac.uk

\section{List of Illustrations}

Fig. 1 Joannes Fyt, The Cock and the Jewel (“Gallinero"), 1660, oil on canvas, 123 x $242 \mathrm{~cm}$. Museo Nacional del Prado, Madrid, inv. no. P001526 (artwork in the public domain) Image: Museo Nacional del Prado, 2021

Fig. 2 Joannes Fyt, The Flemish Cock and the Turkey Cock, ca. 1638-61, oil on canvas, 122 x 158 $\mathrm{cm}$. Koninklijke Musea voor Schone Kunsten van België, Brussels, inv. no. 4420. (artwork in the public domain) Image: RMFAB, Brussels. J. Geleyns - Art Photography

Fig. 3 Joannes Fyt, The Cock and the Jewel, ca. 1638-61, oil on canvas, 118.8 x $153 \mathrm{~cm}$. Sold at Christie's, Amsterdam, April 13, 2010, lot 78. (artwork in the public domain) Image: Christie's

Fig. 4 Joannes Fyt, The Cock and the Jewel (“Gallinero”) (fig. 1), detail. Image: Museo Nacional del Prado, 2021

Fig. 5 Frans Snyders, The Cock and the Jewel, ca. 1616-20, oil on panel, 100 x $67 \mathrm{~cm}$. Suermondt-Ludwig-Museum, Aachen, inv. no. 484 (artwork in the public domain)

Fig. 6 Workshop of Frans Snyders, The Cock and the Jewel, ca. 1620, oil on canvas, $169 \times 240 \mathrm{~cm}$. Auckland Art Gallery, inv. no. 2016/21 (loan). (artwork in the public domain) Image: Auckland Art Gallery Toi o Tāmaki, NZ

Fig. 7 Marcus Gheeraerts, "Den Hane op den messijnk" (The Cock on the dung hill), in Edewaerd de Dene, De warachtighe fabulen der dieren (Bruges: P. de Clerck, 1567), 46. (artwork in the public domain) Image: BNF, Paris

Fig. 8 Melchior de Hondecoeter (attrib.), The Cock and the Jewel, ca. 1670-99, oil on canvas, 121.9 x $165.1 \mathrm{~cm}$. Powis Castle, Powys, inv. no. 1180965. (artwork in the public domain) Image: National Trust Images

Fig. 9 Marcus Gheeraerts, "Vlaemsche ende Turcksche Hane" (The Flemish Cock and the Turkey Cock), in Edewaerd de Dene, De warachtighe fabulen der dieren (Bruges: P. de Clerck, 1567), 190. (artwork in the public domain) Image: BNF, Paris 
Fig. 10 Frans Snyders, The Flemish Cock and the Turkey Cock, ca. 1650-57, oil on canvas, $88.5 \mathrm{x}$ $118.5 \mathrm{~cm}$. Hermitage Museum, Saint Petersburg, inv. no. 655 (artwork in the public domain) Image: Hermitage Museum, Saint Petersburg

Fig. 11 Paul de Vos, The Flemish Cock and the Turkey Cock, ca. 1615-78, oil on canvas, 122 x 185.5 $\mathrm{cm}$. Muzeum Narodowe, Warsaw, inv. no. M.Ob.2504. (artwork in the public domain) Image: National Museum, Warsaw

Fig. 12 Joannes Fyt, The Flemish Cock and the Turkey Cock (fig. 2), detail. Image: RMFAB, Brussels. J. Geleyns - Art Photography

\section{Bibliography}

Acheson, Katherine. “The Picture of Nature: Seventeenth-Century English Aesop's Fables.” Journal for Early Modern Cultural Studies 9, no. 2 (2009): 25-50. https://doi.org/10.1353/jem.0.0032

Aldrovandi, Ulisse. Aldrovandi on Chickens: The Ornithology of Ulisse Aldrovandi (1600), Volume II, Book XIV. Translated by L. R. Lind. Norman: University of Oklahoma Press, 1963.

Alpers, Svetlana. The Decoration of the Torre de la Parada. London: Phaidon, 1971.

Arndt, Karl. “'De gallo et iaspide’: Ein Fabelmotiv bei Frans Snyders.” Aachner Kunstblatter 40 (1971): 186-93.

Ashworth, William, Jr. "Marcus Gheeraerts and the Aesopic Connection in Seventeenth-Century Scientific Illustration." Art Journal 44 (1984): 132-38. https://doi.org/10.1080/00043249.1984.1079 $\underline{2534}$

Aterido, Ángel, Juan Martínez Cuesta, and José Juan Pérez Preciado. Inventarios reales: Colecciones de pinturas de Felipe V e Isabel Farnesio. 2 vols. Madrid: Fundación de Apoyo a la Historia del Arte Hispánico, 2004.

Balfe, Thomas, and Joanna Woodall. "Introduction: From Living Presence to Lively LikenessThe Lives of ad vivum." In Ad Vivum? Visual Materials and the Vocabulary of Life-likeness in Europe Before 1800, edited by Thomas Balfe, Joanna Woodall, and Claus Zittel, 1-43. Leiden: Brill, 2019. https://doi.org/10.1163/9789004393998 002

Balfe, Thomas. "The Animal and the Edible in the Work of Joannes Fyt (1611-61)." PhD diss., University of London, 2014.

Balis, Arnout. "Fabeluitbeeldingen in de 17de-eeuwse Vlaamse Schilderkunst." In Zoom op Zoo: Antwerp Zoo Focusing on Arts and Sciences, edited by Cécile Kruyfhooft, 259-75. Antwerp: Koninklijke Maatschappij voor Dierkunde van Antwerpen, 1985. 
Chapman, H. Perry, Wouter Kloek, and Arthur Wheelock Jr. Jan Steen: Painter and Storyteller. Washington, DC: National Gallery of Art, 1996.

Daston, Lorraine and Elizabeth Lunbeck, eds. Histories of Scientific Observation. Chicago: University of Chicago Press, 2011.

De Bie, Cornelis. Het gulden cabinet vande edele vry schilder-const. Antwerp: Juliaen van Montfort, 1662 .

De Dene, Edewaerd. De warachtighe fabulen der dieren. Bruges: P. de Clerck, 1567.

Díaz Padrón, Matías. El siglo de Rubens en el Museo del Prado: Catálogo razonado de pintura flamenca del siglo XVII. 3 vols. Barcelona: Editorial Prensa Ibérica, 1995.

Driscoll, Kári, and Eva Hoffmann. "Introduction: What Is Zoopoetics?" In What Is Zoopoetics? Texts, Bodies, Entanglement, edited by Kári Driscoll and Eva Hoffmann, 1-13. Basingstoke: Palgrave Macmillan, 2018. https://doi.org/10.1007/978-3-319-64416-5 1

Eiche, Sabine. Presenting the Turkey: The Fabulous Story of a Flamboyant and Flavourful Bird. Florence: Centro Di, 2004.

Erasmus, Desiderius. Collected Works of Erasmus. Toronto: University of Toronto Press, 1974- .

Freitag, Arnoldus. Mythologia ethica: Hoc est moralis philosophiae per fabulas brutis attributas traditoe. Antwerp: Plantin, 1579.

Fudge, Erica. Perceiving Animals: Humans and Beasts in Early Modern English Culture. Urbana: University of Illinois Press, 2002.

Gessner, Conrad. Historice Animalium. Zurich: Froschover, 1551-87.

Golding, Arthur. A Moral Fable-Talk (1586), edited by Richard Barnes. San Francisco: Arion Press, 1987.

Greindl, Edith. Les Peintres flamands de nature morte au XVIIe siècle, rev. ed. Sterrebeek: Michel Lefebvre, 1983.

Guazzo, Stefano. Van den hevschen burgerlycken Ommegangh. Translated by Gomes de Trier. Alkmaar: J. de Meester, 1603.

Hodnett, Edward. Aesop in England: The Transmission of Motifs in Seventeenth-Century Illustrations of Aesop's Fables. Charlottesville: University Press of Virginia, 1979.

Hodnett, Edward. Marcus Gheeraerts the Elder, of Bruges, London, and Antwerp. Utrecht: Haentjens Dekker \& Gumbert, 1971. 
Jorink, Eric, and Bart Ramakers. "Undivided Territory: 'Art' and 'Science' in the Early Modern Netherlands." Nederlands Kunsthistorisch Jaarboek 61 (2011): 7-32. https://doi. org/10.1163/22145966-90000766

Konečný, Lubomír. “Of Fables and Painters." Bulletin of the National Gallery in Prague 1 (1991): $34-43$.

Koslow, Susan. Frans Snyders: The Noble Estate; Seventeenth-Century Still-Life and Animal Painting in the Southern Netherlands. Antwerp: Fonds Mercator Paribas, 1995.

Landwehr, John. Emblem and Fable Books Printed in the Low Countries, 1542-1813: A Bibliography, 3rd rev. ed. Utrecht: HES Publishers, 1988.

Lewis, Jayne. "The Fabular Tradition." In The Oxford History of Classical Reception in English Literature, edited by David Hopkins and Charles Martindale, 477-94. Oxford: Oxford University Press, 2012.

Marr, Alexander. “Knowing Images." Renaissance Quarterly 69, no. 3 (2016): 1000-13.

Middelhoff, Frederike, and Sebastian Schönbeck. "Coming to Terms: The Poetics of More-thanHuman Worlds." In Texts, Animals, Environments: Zoopoetics and Ecopoetics, edited by Frederike Middelhoff, Sebastian Schönbeck, and Roland Borgards, 1-38. Freiburg: Rombach Verlag, 2019.

Moe, Aaron. Zoopoetics: Animals and the Making of Poetry. Lanham: Lexington Books, 2014.

Möller, Lise Lotte. "Der Indianische Hahn in Europa." In Art, the Ape of Nature: Studies in Honor of H. W. Janson, edited by Moshe Barasch and Lucy Freeman Sandler, 313-40. New York: H. W. Abrams, 1981.

Mombarg, Bert. Houden van Kippen: Een Historisch-Sociologische Analyse van de Georganiseerde Raspluimveeteelt. Assen: Van Gorcum, 2000.

Nouwen, Robert. "Hanengevechten in België: Over de Geschiedenis van het Dagelijkse Leven en de Instandhouding van Levend Erfgoed." Volkskunde 105 (2004): 35-50.

Orlandi, Pellegrino Antonio. Abecedario pittorico, rev. ed. Venice: Giambattista Pasquali, 1753.

Peacham, Henry. The Gentleman's Exercise; or an Exquisite Practise: As Well for Drawing All Manner of Beasts in Their True Portraitures. London: John Browne, 1612.

Perry, Ben Edwin. Aesopica: A Series of Texts Relating to Aesop or Ascribed to Him or Closely Connected with the Literary Tradition that Bears His Name. Urbana: University of Illinois Press, 1952. 
Planudes, Maximus. Aesopi Phrygis fabulae elegantissimis eiconibus veras animalium species ad vivum adumbrantes. Lyons: Joan. Tornaesius, 1551.

Ray, John. The Ornithology of F. W. London: John Martyn, 1678.

Rikken, Marrigje, and Paul Smith. "Jan Brueghel's Allegory of Air (1621) from a Natural Historical Perspective.” Nederlands Kunsthistorisch Jaarboek 61 (2011): 86-115. https://doi. org/10.1163/22145966-90000769

Ripa, Cesare. Iconologia, of uytbeeldingen des Verstands. Translated by Dirck Pietersz Pers. Amsterdam: Dirck Pietersz Pers, 1644.

Robels, Hella. Frans Snyders, Stilleben- und Tiermaler, 1579-1657. Munich: Deutscher Kunstverlag, 1989.

Smith, Paul. Het schouwtoneel der dieren: Embleemfabels in de Nederlanden (1567-ca.1670). Hilversum: Verloren, 2006.

Smith, Paul. "Dispositio in the Emblematic Fable Books of the Gheeraerts Filiation (1567-1617)." In Emblems of the Low Countries: A Book Historical Perspective, edited by Alison Adams and Marleen van der Weij, 149-69. Glasgow: University of Glasgow, Department of French, 2003.

Speckenbach, Klaus. "Die Fabel von der Fabel: Zur Überlieferungsgeschichte der Fabel von Hahn und Perle." Frühmittelalterliche Studien 12 (1978): 178-229. https://doi.

org/10.1515/9783110242119.178

Ter Gouw, Johannes. De Volksvermaken. Haarlem: E. F. Bohn, 1871.

Van Gennep, Arnold. Le Folklore de la Flandre et du Hainaut français (département du Nord). 2 vols. Paris: G.-P. Maisonneuve, 1935.

Van Vaeck, Marc. "Sixteenth- and Seventeenth-Century Dutch 'Emblematic' Fable Books from the Gheeraerts Filiation." Emblematica 7 (1993): 25-38.

Vondel, Joost van den. Vorstelijcke Warande Der Dieren: Waer in De Zeden-rijcke Philosophie, Poëtisch, Morael, en Historiael, vermakelijck en treffelijck wort voorghestelt. Amsterdam: Dirck Pietersz, 1617.

Vries, Matthias de, et al. Woordenboek der Nederlandsche Taal. The Hague: M. Nijhoff, 1882-1998.

Wepler, Lisanne. “The Bad Bat: On Two Painted Fables by Pieter Boel in Frankfurt am Main and Munich.” Simiolus 39, no. 4 (2019): 376-87.

Wepler, Lisanne. Bilderzählungen in der Vogelmalerei des niederländischen Barocks. Petersberg: Michael Imhof Verlag, 2014. 
Wepler, Lisanne. “'Verhalen': Bild-Erzählung in der Fabelmalerei bei Melchior d'Hondecoeter und Frans Snijders." In Ad Fontes! Niederländische Kunst des 17. Jahrhunderts in Quellen, edited by Claudia Fritzsche, Karin Leonhard, and Gregor Weber, 349-65. Petersberg: Michael Imhof Verlag, 2013.

Wepler, Lisanne. "Fabulous Birds: Melchior d'Hondecoeter as Storyteller." In Intolerance, vol. 2, Melchior d'Hondecoeter, 1636-1695, edited by Adrienne Kaeppler, 33-59. Düsseldorf: Feymedia Verlagsgesellschaft, 2010.

Wheatley, Edward. Mastering Aesop: Medieval Education, Chaucer, and His Followers. Gainesville: University Press of Florida, 2000.

Woodall, Joanna. "Laying the Table: The Procedures of Still Life." Art History 35, no. 5 (2012): 976-1003. https://doi.org/10.1111/j.1467-8365.2012.00933.x

${ }^{1}$ Notably, Heinrich Steinhöwel's (1412-1482) fable collection appeared in a bilingual German-Latin edition in 1476/77, with the Dutch version following in 1485; see Edward Wheatley, Mastering Aesop: Medieval Education, Chaucer, and his Followers (Gainesville: University Press of Florida, 2000), 19.

${ }^{2}$ Edewaerd de Dene, De warachtighe fabulen der dieren (Bruges: P. de Clerck, 1567). For adaptations of this book, which by 1617 had been translated into French, Latin, and Dutch, see Marc van Vaeck, "Sixteenth- and Seventeenth-Century Dutch 'Emblematic' Fable Books from the Gheeraerts Filiation," Emblematica 7 (1993): 25-38; John Landwehr, Emblem and Fable Books Printed in the Low Countries, 1542-1813: A Bibliography, 3rd rev. ed. (Utrecht: HES Publishers, 1988), 309-91; Paul Smith, "Dispositio in the Emblematic Fable Books of the Gheeraerts Filiation (15671617)," in Emblems of the Low Countries: A Book Historical Perspective, ed. Alison Adams and Marleen van der Weij (Glasgow: University of Glasgow, Department of French, 2003), 149-69; and Paul Smith, Het schouwtoneel der dieren: Embleemfabels in de Nederlanden (1567-ca.1670) (Hilversum: Verloren, 2006).

${ }^{3}$ Arnout Balis has argued convincingly that Rubens initiated the tradition on the basis that a print after a lost fable painting, assignable on stylistic grounds to about 1620 and thus predating the earliest examples by other artists, names him as the inventor of the design. See Arnout Balis, "Fabeluitbeeldingen in de 17de-eeuwse Vlaamse Schilderkunst," in Zoom op Zoo: Antwerp Zoo Focusing on Arts and Sciences, ed. Cécile Kruyfhooft (Antwerp: Koninklijke Maatschappij voor Dierkunde van Antwerpen, 1985), 268-69.

${ }^{4}$ For these fable painters and the influence of Snyders, see Balis, "Fabeluitbeeldingen," 259-75; Lubomír Konečný, "Of Fables and Painters," Bulletin of the National Gallery in Prague 1 (1991): 34-43; Hella Robels, Frans Snyders, Stilleben- und Tiermaler, 1579-1657 (Munich: Deutscher Kunstverlag, 1989), 93-97, 309-22; Susan Koslow, Frans Snyders: The Noble Estate; Seventeenth-Century Still-Life and Animal Painting in the Southern Netherlands (Antwerp: Fonds 
Mercator Paribas, 1995), 259-69; and Lisanne Wepler, Bilderzählungen in der Vogelmalerei des niederländischen Barocks (Petersberg: Michael Imhof Verlag, 2014); Lisanne Wepler, "The Bad Bat: On Two Painted Fables by Pieter Boel in Frankfurt am Main and Munich," Simiolus 39, no. 4 (2019): 376-87.

${ }^{5}$ For Snyders's fable books, see Koslow, Frans Snyders, 259. That Fyt was Snyders's pupil is noted in Pellegrino Antonio Orlandi, Abecedario pittorico, rev. ed. (Venice: Giambatista Pasquali, 1753), 250.

${ }^{6}$ The most recent catalogue only lists Fyt's still lifes: Edith Greindl, Les Peintres flamands de nature morte au XVIIe siècle, rev. ed. (Sterrebeek: Michel Lefebvre, 1983), 95-107, 348-54. Three of Fyt's fables depict poultry birds and are discussed here (see n. 50 below for the third). Wepler, "Bad Bat," 381-82, identified an allusion to the fable called The Fearful Hares in a fourth painting. I have not yet seen this work, and so it is not discussed here.

${ }^{7}$ Balis, "Fabeluitbeeldingen"; Koslow, Frans Snyders; Wepler, Bilderzählungen, "Bad Bat." References in these studies to the fables by Fyt discussed here are given in the notes that follow.

${ }^{8}$ For the historiography, see Eric Jorink and Bart Ramakers, "Undivided Territory: 'Art' and 'Science' in the Early Modern Netherlands,' Nederlands Kunsthistorisch Jaarboek 61 (2011): 7-32 HTTPS://DOI.ORG/10.1163/22145966-90000766; Lorraine Daston and Elizabeth Lunbeck, eds., Histories of Scientific Observation (Chicago: University of Chicago Press, 2011), 1-11; and Alexander Marr, "Knowing Images," Renaissance Quarterly 69, no. 3 (2016): 1000-1.

${ }_{9}^{9}$ William Ashworth Jr., "Marcus Gheeraerts and the Aesopic Connection in Seventeenth-Century Scientific Illustration," Art Journal 44 (1984): 132-38 HTTPS://DOI.ORG/10.1080/00043249.1984 .10792534; Smith, "Dispositio"; Katherine Acheson, "The Picture of Nature: Seventeenth-Century English Aesop’s Fables," Journal for Early Modern Cultural Studies 9, no. 2 (2009): 25-50 HTTPS:// DOI.ORG/10.1353/JEM.0.0032; Lisanne Wepler, "Fabulous Birds: Melchior d'Hondecoeter as Storyteller," in Intolerance, vol. 2, Melchior d'Hondecoeter, 1636-1695, ed. Adrienne Kaeppler (Düsseldorf: Feymedia Verlagsgesellschaft, 2010), 33-59; Wepler, "Bad Bat."

${ }^{10}$ Aristotle, The History of Animals, 9.49b, 633a, in Jonathan Barnes, ed., The Complete Works of Aristotle: The Revised Oxford Translation (Princeton: Princeton University Press, 1984), 1:984.

${ }^{11}$ Ulisse Aldrovandi, Aldrovandi on Chickens: The Ornithology of Ulisse Aldrovandi (1600), Volume II, Book XIV, trans. L. R. Lind (Norman: University of Oklahoma Press, 1963), 38, noting Diogenes Laertius's anecdote about the poet Solon; John Ray, The Ornithology of F. W. (London: John Martyn, 1678), 156.

${ }^{12}$ See Aaron Moe, Zoopoetics: Animals and the Making of Poetry (Lanham: Lexington Books, 2014). Overviews include Kári Driscoll and Eva Hoffmann, "Introduction: What Is Zoopoetics?," in What Is Zoopoetics? Texts, Bodies, Entanglement, ed. Kári Driscoll and Eva Hoffmann (Basingstoke: Palgrave Macmillan, 2018), 1-13 HTTPS://DOI.ORG/10.1007/978-3-319-64416-5_1; and Frederike Middelhoff and Sebastian Schönbeck, "Coming to Terms: The Poetics of Morethan-Human Worlds," in Texts, Animals, Environments: Zoopoetics and Ecopoetics, ed. Frederike Middelhoff, Sebastian Schönbeck, and Roland Borgards (Freiburg: Rombach Verlag, 2019), 1-38. ${ }^{13}$ Moe, Zoopoetics, $11 \mathrm{ff}$.

${ }^{14}$ This is an ingrained tendency in much of the scholarship on early modern fable imagery, which, while recognizing the convincing character of the animals and environments in particular depictions, often presents this as separable from, or ancillary to, the allegedly more primary function of narration or the transmission of visual information ("naturalism"). See, for example, the productive but explicitly binary distinction between fable texts concerned with moral and political 
meanings and fable images concerned with picturing nature in Acheson, "Picture of Nature," 30-31 HTTPS://DOI.ORG/10.1353/JEM.0.0032. The historiographical opposition between narration and "naturalism" is discussed in Wepler, "Fabulous Birds," 37ff. For a critique of the surface/depth model of interpretation as applied to Netherlandish art, see Joanna Woodall, "Laying the Table: The Procedures of Still Life," Art History 35, no. 5 (2012): 978-82 HTTPS:// DOI.ORG/10.1111/J.1467-8365.2012.00933.X.

${ }^{15}$ Moe, Zoopoetics, 7, 24-26.

${ }^{16}$ Middelhoff and Schönbeck, "Coming to Terms," $14 \mathrm{ff}$.

${ }^{17}$ Driscoll and Hoffmann, "Introduction," 3 HTTPS://DOI.ORG/10.1007/978-3-319-64416-5_1.

${ }^{18}$ Moe, Zoopoetics, 18; Driscoll and Hoffmann, "Introduction," 3 HTTPS://DOI.

ORG/10.1007/978-3-319-64416-5_1. An example of the earlier stance that views fable animals purely as a product of human imagination is Erica Fudge, Perceiving Animals: Humans and Beasts in Early Modern English Culture (Urbana: University of Illinois Press, 2002), 73.

${ }^{19}$ For an overview of early modern attitudes toward fable, see Jayne Lewis, "The Fabular Tradition," in The Oxford History of Classical Reception in English Literature, ed. David Hopkins and Charles Martindale (Oxford: Oxford University Press, 2012), 477-94.

${ }^{20}$ Svetlana Alpers, The Decoration of the Torre de la Parada (London: Phaidon, 1971); Koslow, Frans Snyders, 259-62.

${ }^{21}$ For the Antwerp inventory evidence relating to Fyt, which indicates that his works were mainly purchased by merely well-to-do rather than extremely wealthy collectors, see Thomas Balfe, "The Animal and the Edible in the Work of Joannes Fyt (1611-61)" (PhD diss., University of London, 2014), 292-93.

${ }^{22}$ The date is on the small plaque at lower right. For provenance information and bibliography, see Matías Díaz Padrón, El siglo de Rubens en el Museo del Prado: Catálogo razonado de pintura flamenca del siglo XVII (Barcelona: Editorial Prensa Ibérica, 1995), 1:570. For the full inventory entry, see Ángel Aterido, Juan Martínez Cuesta, and José Juan Pérez Preciado, Inventarios reales: Colecciones de pinturas de Felipe V e Isabel Farnesio (Madrid: Fundación de Apoyo a la Historia del Arte Hispánico, 2004), 2:59, nos. 477-78: "La otra Gallinero con Gallinas, y su comedero enrejado" (The other [work] a poultry piece with chickens, and their latticed feeder).

${ }^{23}$ Joannes Fyt, The Cock and the Jewel, ca. 1638-61, oil on canvas, 118.6 x $154.5 \mathrm{~cm}$, signed ("J. Fijt. f."), sold at Christie's, Amsterdam, April 13, 2010, lot 78, and May 7, 2013, lot 81; and at the Dorotheum, Vienna, October 18, 2016, lot 42; RKD no. 18276. For the identification of the fable, see Wepler, Bilderzählungen, 34 note 78.

${ }^{24}$ For the couple's collecting activities, see Aterido et al., Inventarios reales.

${ }^{25}$ Díaz Padrón, El siglo de Rubens, 1:570.

${ }^{26}$ Ben Edwin Perry, Aesopica: A Series of Texts Relating to Aesop or Ascribed to Him or Closely Connected with the Literary Tradition that Bears His Name (Urbana: University of Illinois Press, 1952), no. 503. The allusion to fable is discussed in Balfe, “The Animal," 189-201; Wepler, Bilderzählungen, 19, 28.

${ }^{27}$ The classic study of the fable is Klaus Speckenbach, "Die Fabel von der Fabel: Zur Überlieferungsgeschichte der Fabel von Hahn und Perle," Frühmittelalterliche Studien 12 (1978): 178-229HTTPS://WWW.DEGRUYTER.COM/DOCUMENT/DOI/10.1515/9783110242119.178/ HTML.

${ }^{28}$ The fable is described in an Antwerp prose edition of Aesop's fables as known even "to purblind simpletons and barbers ... there is not any that is more familiar to the ordinary folk" (lippis \& 
tonsoribus sit notissima, neque ulla alia quae vulgo sit familiarior): Arnoldus Freitag, Mythologia ethica: Hoc est moralis philosophiae per fabulas brutis attributas traditoe (Antwerp: Plantin, 1579), 102.

${ }^{29}$ Stefano Guazzo, Van den hevschen burgerlycken Ommegangh, trans. Gomes de Trier (Alkmaar: J. de Meester, 1603), 193.

${ }^{30}$ De Dene, De warachtighe fabulen, 47: "Datmen niet en bezicht, achtmen wel cleen. / Insghelijcx hebben sij een aerdtsch ghemoedt / En sijn onvroedt / Die voor den gheest kiesen vleesch en bloedt / Die inder aerden schrapen meest t’allen tijden / Zoorch vuldich en grijpghierich zijn naer t'goedt / Dat vergruwelic is, en soo veel quaden doedt / Die metter spoedt: / Wetentheyt ende wijsheyt terden onder voet / Ende God oock gheheel stellen besijden, / Laetende die claerheyt voorby lijden."

${ }^{31}$ Van den Vondel, Vorstelijcke Warande Der Dieren, no. 113: “'Ghekroonde Vogel wijs! kont ghij dijn meerder leeren, / Haer wulpsche dartelheyt, en diere pronckerij / Verachten en vertreen? dus mensche wilt u keeren, / En spiegelt doch aen hem u prael en hoverdij. / De Peerle' is oock de konst der wijse en hooghgheleerde, / Die van d'ontwetende' Haen verniet wort en verneert: / Vytwendighlijck, en is cieraet van geender weerde, / Soo ghij inwendichlijck nootdrufticheyt ontbeert.”

${ }^{32}$ For versions of the fable that portray the cock positively, see Speckenbach, "Die Fabel," 202-4 HTTPS://WWW.DEGRUYTER.COM/DOCUMENT/DOI/10.1515/9783110242119.178/HTML. ${ }^{33}$ Cesare Ripa, Iconologia, of uytbeeldingen des Verstands, trans. Dirck Pietersz Pers (Amsterdam: Dirck Pietersz Pers, 1644), 346: "De Haen is uyter Natuyre naerstigh en besorght, en in 't schrafelen en soecken vertoont hy groote naerstigheyt, ter tijd toe hy vind, 't geene hem behaeghlijck is, onderscheydende alsoo de onnutte koorentjens van de nutte, die hem tot zijn kost en voedsel strecken."

${ }^{34}$ For ornithological works potentially known to Antwerp artists, see Koslow, Frans Snyders, 289.

${ }^{35}$ Aldrovandi, Aldrovandi on Chickens, 144-45.

${ }^{36}$ The Aachen picture, possibly the earliest large-scale Flemish fable painting, has generated a small historiography: Karl Arndt, “De gallo et iaspide': Ein Fabelmotiv bei Frans Snyders," Aachner Kunstblatter 40 (1971): 186-93; Balis, "Fabeluitbeeldingen," 274; Koslow, Frans Snyders, 268. ${ }^{37}$ Earlier printed images of the fable are surveyed in Edward Hodnett, Aesop in England: The Transmission of Motifs in Seventeenth-Century Illustrations of Aesop's Fables (Charlottesville: University Press of Virginia, 1979), 124-25. The Gheeraerts etching was evidently well known to Netherlandish artists as indicated by drawn copies, e.g. Johannes Wierix, The Cock and the Jewel, undated, pen and brown ink on vellum, 6.1 x $5.3 \mathrm{~cm}$. British Museum, London, museum no. 1946,0713.202.

${ }^{38}$ This composition was also copied, e.g. Adriaen van Utrecht (after), The Cock and the Jewel, ca. 1650-99, oil on canvas, 115.5 x 165.5 cm, sold at Sotheby's, New York, January 14, 1994, lot 195; and at Sotheby's, Amsterdam, May 6, 1998, lot 119; RKD no. 46005. For this and other variants produced later in the century, see Wepler, Bilderzählungen, 28-29.

${ }^{39}$ Moe, Zoopoetics, 7. Emphasis in the original.

${ }^{40}$ Fyt's expansive handling of fable also raises the possibility that the beholder will not notice the ring, or not immediately, or not without it being pointed out. Audiences meeting in a sociable context might have relished the interplay in the painting between its oblique adaptation of the fable and its thematic concern with the value of diligent attention.

${ }^{41}$ The toppled terracotta pot, evidence of recent human activity, might have called to mind the 
famous aphorism ollas ostentare (“To make a display of pots"), which is interpreted in Erasmus's Adagia (1500) as expressing the idea that humble, everyday material phenomena can open the mind to wisdom. This resonates with the questions over the value of material phenomena raised by the painting and expands its sphere of reference to encompass proverb as well as fable; see Erasmus, Collected Works, 31:94, proverb 2.2.40.

${ }^{42}$ Aldrovandi, Aldrovandi on Chickens, 131-41, 129.

${ }^{43}$ Conrad Gessner, Historice Animalium (Zurich: Froschover, 1551-87), book 3 (1555), 425:

"Gallinae domesticae in calidioribus \& bene munitis ab aëris \& frigoris aditu locis sunt educandae, in quibus fumus quidam exurgit. In parietibus autem ipsis mansiunculas facere expedit, ut in eis pariant" (Domestic poultry should be reared in warm places and well sheltered from the encroachment of winds and the cold, and where smoke rises. In the walls it is helpful to make alcoves so that they lay their eggs there).

${ }^{44}$ Aldrovandi, Aldrovandi on Chickens, 57.

${ }^{45}$ Aldrovandi, Aldrovandi on Chickens, 57.

${ }^{46}$ In a parallel manner, Aldrovandi and Gessner's proto-scientific works incorporate knowledge from the "fictive" mode of fable, including The Cock and the Jewel; see e.g. Aldrovandi, Aldrovandi on Chickens, 246, 258.

${ }^{47}$ In Antwerp there was sufficient demand for the book for it to be reprinted by the Plantin Press in 1615 and 1653, though many earlier and foreign versions were also in circulation; see Desiderius Erasmus, Collected Works of Erasmus (Toronto: University of Toronto Press, 1974-), 24:280-83. For other authorities who discuss the function and value of fable, see Koslow, Frans Snyders, 265-67.

${ }^{48}$ Erasmus, Collected Works, 24:632; my emphasis.

${ }^{49}$ Erasmus, Collected Works, 24:585.

${ }^{50}$ Koslow, Frans Snyders, 287-90. Fyt himself contributed to this trend in another fable picture, The Partridge and the Cocks; for this fable, see Perry, Aesopica, no. 23. Fyt's adaptation exists in two main versions: (1) Joannes Fyt, ca. 1638-61, oil on canvas, 108 x $158 \mathrm{~cm}$, signed ("Joannes. FYT.”), Koninklijke Musea voor Schone Kunsten van België, Brussels, inv. no. 7824, RKD no. 184541; (2) Joannes Fyt (after), ca. 1638-61, oil on canvas, 114 x 167 cm, Museo Nacional del Prado, Madrid, inv. no. P001532, RKD no. 18272. There is also a doubtfully attributed work in which the fight occurs in an outdoor setting: Joannes Fyt (attributed), ca. 1638-61, oil on canvas, 120 x 205 cm, sold at Paleis voor Schone Kunsten, Brussels, June 5, 1957, lot 154, RKD no. 18401. For discussion of this work, see Balis, "Fabeluitbeeldingen," 263 (where the fable allusion is identified); Balfe, “The Animal," 209-17; Wepler, Bilderzählungen, 169-70.

${ }^{51}$ Arnold van Gennep, Le Folklore de la Flandre et du Hainaut français (département du Nord) (Paris: G.-P. Maisonneuve, 1935), 2:724; Robert Nouwen, "Hanengevechten in België: Over de Geschiedenis van het Dagelijkse Leven en de Instandhouding van Levend Erfgoed," Volkskunde 105 (2004): 35-50.

${ }^{52}$ The rare depictions of cockfighting by Netherlandish artists usually portray it as a vulgar activity; see H. Perry Chapman, Wouter Kloek, and Arthur Wheelock Jr., Jan Steen: Painter and Storyteller (Washington, DC: National Gallery of Art, 1996), 136-38. That Flemish elites did practice the sport is indicated by the cockfight held in the council hall of 's-Hertogenbosch on Shrove Tuesday from 1318 to 1566 to celebrate the founding of the religious confraternity known as the Illustre Lieve Vrouwe Broederschap (Illustrious Brotherhood of Our Blessed Lady); see Johannes ter Gouw, De Volksvermaken (Haarlem: E. F. Bohn, 1871), 357-58; Bert Mombarg, Houden van 
Kippen: Een Historisch-Sociologische Analyse van de Georganiseerde Raspluimveeteelt (Assen: Van Gorcum, 2000), 45. For more on cockfighting in the city, see Aldrovandi, Aldrovandi on Chickens, 154.

${ }^{53}$ Fyt's painting was first identified as a depiction of the fable by Balis, "Fabeluitbeeldingen," 266; Smith, Schouwtoneel der dieren, 15, has underlined de Dene's innovativeness in inventing a fable focusing on a newly discovered animal. For more on paintings of this fable, see Lisanne Wepler, “"Verhalen': Bild-Erzählung in der Fabelmalerei bei Melchior d'Hondecoeter und Frans Snijders," in Ad Fontes! Niederländische Kunst des 17. Jahrhunderts in Quellen, ed. Claudia Fritzsche, Karin Leonhard, and Gregor Weber (Petersberg: Michael Imhof Verlag, 2013), 349-65.

${ }^{54}$ Cornelis de Bie, Het gulden cabinet vande edele vry schilder-const (Antwerp: Juliaen van Montfort, 1662), 339: “Soo naer t'leven staen de dieren / En hier op panneelen swieren: / Die van Fyt gheschildert sijn / Jeder thoont een levens schijn" (So lifelike are the animals painted by Fyt, moving here on their painted panels, each displaying a lively appearance). Note also de Bie's use of naer t'leven, the Flemish variant of the Latin phrase ad vivum (lifelike, "from or to [the] life"), which was frequently applied to human-made images perceived as conveying useful, reliable knowledge; see Thomas Balfe and Joanna Woodall, "Introduction: From Living Presence to Lively Likeness-The Lives of ad vivum," in Ad Vivum? Visual Materials and the Vocabulary of Life-likeness in Europe before 1800, ed. Thomas Balfe, Joanna Woodall, and Claus Zittel (Leiden: Brill, 2019), 1-9. HTTPS://DOI.ORG/10.1163/9789004393998_002

${ }^{55}$ Van den Vondel, Vorstelijcke Warande Der Dieren, no. 99: "Den Kalikoet in't eynd zagh dat den Duytschen-Haen / Hem rust noch vrede liet: dus om zich gants tontslaen / Van allerhande twist, verkoos in ander hoecken / Zijn daghelijcxsen kost in vrede te gaen zoecken. 'Veel volckren zijn zoo wilt, zoo woest en onbesuyst, / 'Dat d'arme vreemdling niet bij haer magh zijn gehuyst. / 'Al hebben zij een land tot haer behoef ghewonnen, / 'Een ander zullen zij het aerdrijck noch misgonnen.”

${ }^{56}$ The word "kalikoet" for turkey, referring to the bird's perceived origins in Calcutta, was probably not available to de Dene in the 1560s. Matthias de Vries et al., Woordenboek der Nederlandsche Taal (The Hague: M. Nijhoff, 1882-1998), gives its first usage as 1582.

${ }^{57}$ De Dene, Warachtige fabulen, 191: "Insghelijcx zommich ziet een van vremder natie / Den noodtdurst bezouckende om mueghen leven / Zij doender asionstich op murmuratie / Niet rustende voor zij hem hebben verdreven."

${ }^{58}$ Arthur Golding, A Moral Fable-Talk (1586), ed. Richard Barnes (San Francisco: Arion Press, 1987), 282; my emphasis.

${ }^{59}$ Lise Lotte Möller, "Der Indianische Hahn in Europa," in Art, the Ape of Nature: Studies in Honor of H. W. Janson, ed. Moshe Barasch and Lucy Freeman Sandler (New York: H. W. Abrams, 1981), 326-27; see also Sabine Eiche, Presenting the Turkey: The Fabulous Story of a Flamboyant and Flavourful Bird (Florence: Centro Di, 2004).

${ }^{60}$ The pairing of the cock and turkey as combatants in paintings of the avian kingdom by Jan Brueghel and his collaborators indicates that they were still regarded as antagonistic close relatives well into the seventeenth century; see Marrigje Rikken and Paul Smith, "Jan Brueghel's Allegory of Air (1621) from a Natural Historical Perspective," Nederlands Kunsthistorisch Jaarboek 61 (2011): 103-4 HTTPS://DOI.ORG/10.1163/22145966-90000769.

${ }^{61}$ For the possible political content of the fables, see the discussion by Richard Barnes in Golding, Moral Fable-Talk, 28-31, 314-15, 324, 325. 
Recommended Citation:

Thomas Balfe, "Learned Fable, Living World: Artistry, Knowledge and Attention to Nature in Two Aesopic Paintings by Joannes Fyt," Journal of Historians of Netherlandish Art 13:1 (Winter 2021) D0I: 10.5092/jhna.2021.13.1.3 